\title{
Innovation and Collaboration of Movement Removing Stigma Corona Virus Disease (Covid-19)
}

\author{
Aris Sunandar ${ }^{1 *}$ Budi Setiyono $^{2}$ Hardi Warsono ${ }^{3}$ Budiyono $^{4}$ \\ ${ }^{1}$ Department of Public Administration, Universitas Diponegoro, Semarang, Central Java \\ ${ }^{2,3}$ Faculty of Social and Political Science, Universitas Diponegoro, Semarang, Central Java. \\ ${ }^{4}$ Faculty of Public Health, Universitas Diponegoro, Semarang, Central Java. \\ *Corresponding author.Email: arissunandar@students.undip.ac.id
}

\begin{abstract}
Coronavirus disease (COVID-19) is a new disease whose transmission process is very fast, has not found a cure yet, and leads to death. This triggers social stigma in the community. From a health perspective, social stigma is a negative relationship between a person, a group of people sharing certain characteristics and diseases. This stigma encourages concealment to avoid discrimination, prevents immediately seeking health care, and prevents the adoption of healthy behavior. This condition affected the handling of the spread of the Covid-19 pandemic disease. The ostracism having occurred lately is a condition of excessive fear from the community towards positive patients with Covid-19. This condition is caused by a tendency for fear of something and connecting a great sense of worry to different groups. This is a fact existing in the current social order. Although People in Monitoring (ODP) and Patients in Oversight (PDP) have carried out independent isolation, some people still consider that suffering from this disease is a disgrace, and some even close access in and out of the house during independent isolation. This is contrary to the government's recommendations which should work together to fight against Covid-19. Therefore, this article seeks to discuss how innovation and collaboration must be carried out to erase the social stigma arising in the midst of society related to Covid-19. The final results of this article relate to innovations and collaborations carried out to combat and eliminate, namely through the Advocacy, Coordination and Education activities of Kelet District Hospital to ensure social resilience, through periodic monitoring and home visite with relevant stakeholders.
\end{abstract}

\section{Keywords: Transmission Disease, Advocacy, Social Resilience, Stigma, Covid-19}

\section{INTRODUCTION}

Coronavirus disease (COVID-19) is a new disease with a very fast transmission process for which no cure has been found, and leading to death and in turn triggering social stigma in society [1]. On March 11, 2020, WHO officially announced that Covid-19 is a pandemic [2]. In Indonesia, the first 2 cases were found on March 2, 2020, and continued to increase on May 15, 2020, at 09.42 WIB, there were 16,006 confirmed cases (with the addition of 568 new cases), 3,518 recovered, and as many as 1,043 deaths (with an additional 15 new death cases) [3]. In Central Java, on the same date there were 1,066 confirmed cases, 229 recovered and 66 deaths [4].
WHO (2020) explains that a health perspective on social stigma is a negative relationship between a person or group of people with certain characteristics and diseases such as labeling, stereotyping, discrimination, being treated differently, and/or experiencing status deprivation due to a relationship with a disease. Thus, it influences the behavior of a person hiding disease to avoid discrimination, and preventing him from seeking health care immediately and from adopting healthy behavior [5]. This condition also impacts negatively not only those suffering from the disease but also their caregivers, family, friends and the community as well as health workers. The patient and his family were isolated by the community, the nurse was asked to move to a boarding house and even his body was refused burial. This is the 
social stigma occurring within society. Misconception, rumor and misinformation contribute to stigma and discrimination. Communication can correct misunderstandings, promote the importance of prevention, life-saving measures, screening, and early treatment, share sympathetic narratives that humanize the experiences and struggles of individuals or groups affected by Covid-19 and stop the spread of the stigma of Covid-19 [5].

The Regional Government has implemented a communication strategy using coercive, informative, canalizing, educational, persuasive and redundant techniques in packaging messages in the form of instructions, appealing to the public to prevent Covid-19 transmission in their respective regions. However, the central and local governments have not played a maximum role yet in using a comprehensive communication strategy [6]. Communication in the socialization design is very strategic in every policy implementation but it has not been followed up quickly and precisely with the dissemination to the whole community. Thus, collaborative management is needed in handling Covid-19. Collaborative governance is a government arrangement that directly involves nongovernment stakeholders in a formal, consensus-oriented, and a deliberative collective decision-making process aimed at making or implementing public policies, managing public programs or assets [7]. Thus, we need public policy innovation in its implementation. Innovation is new ideas about products, information and technology perceived by individuals or general public. Types of public policy innovation include process innovation, method innovation, and product innovation [8].

Innovation and collaborative governance in handling Covid-19 expectedly will increase social resilience and reduce the stigma of Covid-19 in society.

\section{LITERATURE REVIEW}

First discovered, this virus was called the 2019 novel coronavirus or abbreviated as 2019-nCoV, a designation based on the genetic structure to facilitate the development of diagnostic tests, vaccines and drugs [9] Coronavirus disease (COVID-19) is a new disease with a very fast transmission process for which no cure has been found, and leads to death, in turn triggering social stigma in society [1]. Stigma is a well-documented barrier to health-seeking behavior, involvement in care and adherence to treatment across a range of health conditions globally [10]. Perceived stigma is a social construction characterized with distinguishing the social disgrace attached to other people to identify and devalue them [11]. Social stigma from a health perspective is a negative relationship between a person or group of people who with certain characteristics and diseases such as labeling, stereotyping, discrimination, being treated differently, and/or experiencing status deprivation because of a relationship with a disease. Thus, it influences the behavior of a person hiding disease to avoid discrimination, and preventing people from seeking health care immediately and from adopting healthy behavior [5]. The consensus of stigma research explains 1) a microsocial approach, related to the study of individual and inter-individual stigma with psychological work (social), and 2) a macrosocial approach, related to grouplevel analysis (social/cultural) and structural and sociological works [12]. This condition affects negatively not only those suffering from the disease but also their caregivers, family, friends and community as well as health workers. Misconception, rumor and misinformation contribute to stigma and discrimination. Communication can correct misunderstandings, promote the importance of prevention, life-saving measures, screening, and early treatment, share sympathetic narratives that humanize the experiences and struggles of individuals or groups affected by Covid-19 and stop the spread of the stigma of Covid-19 [5].

Collaborative governance is a government arrangement directly involving non- government stakeholders in a formal, consensus- oriented, and deliberative collective decision- making process aimed at making or implementing public policies, managing public programs or assets [7]. Governance focuses on interestbased negotiations and the bargaining of mutual benefits (Fisher, Ury, and Patton 1991; Raiffa 1982) and informs alternative dispute resolution practices, conflict management, and consensus-building in employment relations, personnel management, contracts, and policies, environment and the public (Goldberg, Sanders, and Rogers 1992; O'Leary and Bingham 2003; Susskind, McKearnan, and Thomas-Larmer 1999). Collaborative Dynamics include: 1) principled engagement, including discovery, definition, deliberation, and determination; 2) mutual motivation, namely: mutual trust, mutual understanding, internal legitimacy, joint commitment; and 3 ) collective action capacity: regulatory/institutional procedures, leadership, knowledge, resources [13]

Innovation is new ideas about products, information and technology perceived by individuals or the general public. Types of public policy innovation include process innovation, method innovation, and product innovation [8]. Policy process innovation emphasizes on the efficiency and effectiveness of the improvement of internal and external work process quality by various stakeholders so that the community gets excellent service renewal. Policy method innovation is based on new policy models and strategies to achieve the goals more optimally with the following criteria: 1) organizational policies that outline new ways of carrying out organizational work processes, 2) old ways or methods of organizations are ineffective and profitable, 3) macro in nature and applicable to a wide field. Policy product innovation is based on the renewal of various products that have been produced by the organization to increase competitiveness with the following criteria: 1) usable or enjoyable directly to customers, 2) internal organizational processes are directly involved and actively produce output enjoyed by customers, 3) produce successful products that is increasing quality and qualified [14]. 


\section{METHODS}

This qualitative research was conducted with a case study approach. Data collection was carried out through indepth interviews, documentation, direct observation, participant observation, and physical artifacts [15] regarding the stigma of Covid-19 in People Under Monitoring (ODP), Patients Under Supervision (PDP) and their families, officials, community leaders, Puskesmas and the Donorojo District Government Conference (Muspika), Jepara Regency.

\section{RESULTS AND DISCUSSIONS}

There were a total of 41 ODPs and 5 PDPs in Donorojo District during May-April 2020. Community anxiety and fear leading to the stigma and discrimination of ODP and PDP continues even by their own families, starting from not being allowed to enter his own house, sleeping outside the house to the closure of road access.

\subsection{Advocacy and Collaboration}

This condition prompted the mobile health team of URK (Leprosy Rehabilitation Unit) Donorojo RSUD Kelet to initiate providing health education with the concept that prevention is better than cure. This idea was communicated to the head of the Donorojo sub-district as the regional stakeholder and the Puskesmas as the person in charge of regional health. The concept of idea offered is to check the conditions of the ODPs and PDPs enlisted in their respective homes by providing counseling on the management of Covid-19 as well as a vehicle for reducing the stigma of Covid-19.

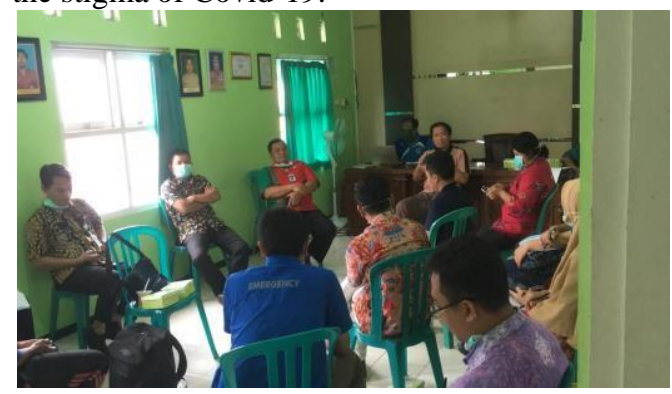

Figure 4.1.1. Presentation of ideas and advocacy to Puskesmas/health stakeholders

This is in accordance with the opinion of Aikins (2006) stating that microsocial is related to the study of individual and inter-individual stigma with psychological work (social) making a person discriminate his own family. Emerson's opinion (2011) states that one of the collaborative dynamics includes the principle of attachment including: discovery, definition, deliberation, and determination [13]. Covid-19 discrimination and stigma have been found even from their own families. URK Donorojo defines that stigma can be overcome through communication with outreach and home visits.
Then it was discussed with the sub-district head as the stakeholder in sub-district area to agree the implementation of the idea.

The first discussion between the Head of SubDistrict and the Regional Secretariat, and the URK Team of Donorojo RSUD Kelet delivered a design of a home visit to ensure health at home rather than the admission to hospital actually increasing stress and reducing the patient's immunity; it also decided to have a complete audience with the Donorojo Muspika team the following day. The audience along with Muspika Donorojo discussed several obstacles including how to identify ODP and PDP while Muspika did not have data. Meanwhile, only hospitals and health centers have the data. It was agreed that the data flow could be accessed through the Covid-19 task force of Jepara Regency, in which there was a chief police as a law enforcer, to be forwarded to the sub-district head and then to each village. Thus no one is blamed for violating patient confidentiality regulations. In addition, it was also agreed that there was no mention of ODP, PDP, or even COVID to the enlisted people, but by informing them that because they had travelled/come back home, a home visit was made to ensure that their conditions were okay. It was agreed that a joint home visit between the Donorojo URK Mobile Team along with village officials and village midwives serve as the representatives of the Puskesmas as well as Babinsa and Babinkamtibmas. Home visits are carried out at least 2 times, the first one during the identification of the followup cases and the second on the fifth or tenth day for case evaluation while ensuring that the drugs given are taken by those found with symptoms. A meeting was scheduled to be held between Muspika, Kades, Head of Puskesmas, community leaders and URK Donorojo on the following Monday.

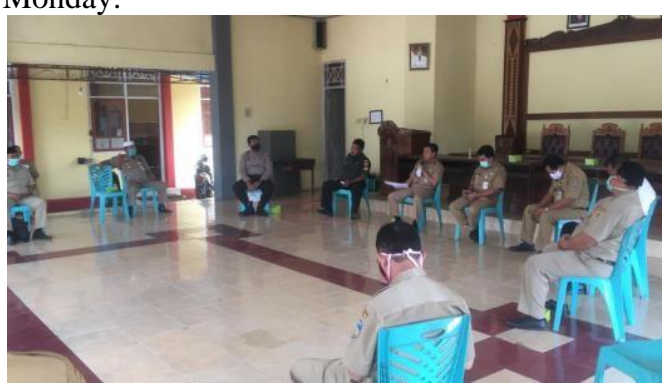

Figure 4.1.2. Hearing, presenting ideas and advocacy to the staff of Muspika Donorojo

This condition is in line with collaborative governance where governmental arrangements directly involve non-government stakeholders in a formal, consensus-oriented, and deliberative collective decisionmaking process aimed at making or implementing public policies, managing programs or public assets [7] which better to prevent than to cure. This governance focuses on interest-based negotiations and the bargaining of mutual benefits (Fisher, Ury, and Patton 1991; Raiffa 1982) and informs alternative dispute resolution practices, conflict management, and consensus-building in employment relations, personnel management, contracts, and policies, 
environment and the public (Goldberg, Sanders, and Rogers 1992; O'Leary and Bingham 2003; Susskind, McKearnan, and Thomas-Larmer 1999) [13], when there were problems with access to ODP and PDP data related to patient secrets that must be maintained. It is in line with Stangl (2019) explaining that advocacy with policymakers and community leaders about the benefits of transmission prevention programs is combined with training of law enforcement officers on harm reduction and proper law enforcement [10] related to the role of Head of SubDistrict, Kapolsek, Danramil, Head of Puskesmas, Officials in reducing the risk of transmission and stigma of COVID-19.

The meeting was scheduled but has not been held yet for the death of a PDP who was not a Donorojo resident but died in the Donorojo area. The study of the corpse ran smoothly even though there were obstacles and the deliberation had been hindered by the fears and worries of the community and their families. The meeting on following Monday agreed a home visit, as agreed upon by Muspika, and added the budget allocation in the Village Fund to support the life of registered ODP and PDP during quarantine period and to prepare PPE for the process of reviewing the body.

This incident is in accordance with Emerson (2011) arguing that collaborative dynamics include mutual motivation, namely mutual trust, mutual understanding, internal legitimacy, joint commitment and collective action capacity: regulatory/institutional procedures, leadership, knowledge, resources [13], characterized with an agreement for the allocation of the village fund budget to life assistance for those quarantined and the availability of PPE for the monitoring of the corpse so that social resilience initiation appears.

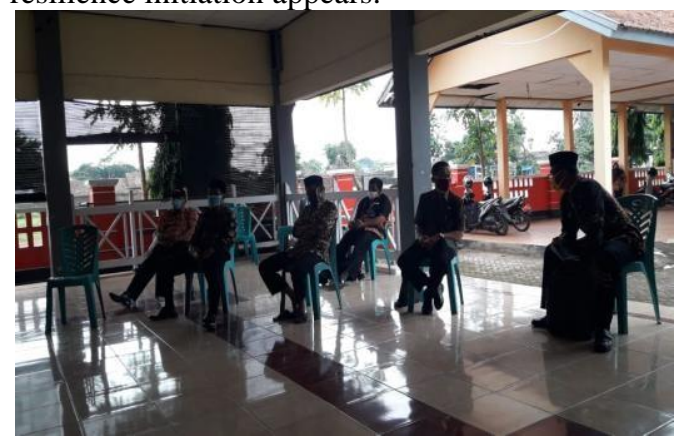

Figure 4.1.3. Coordination of the Village Head and Muspika Donorojo

\subsection{Implementation of Home Visits}

Following this agreement, the Donorojo URK Mobile Team began a visit to the ODP and PDP houses in each village. It started with communication, socialization and coordination with the Head and Village Officials for subsequent home visits with village officials, village midwives, Babinsa and Babinkamtibmas.

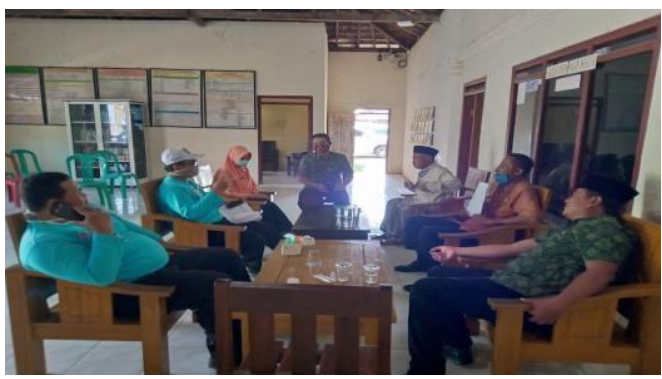

Figure 4.2.1 Socialization and Coordination with Village Officials and Village Midwives

During a home visit, it was explained earlier by the village apparatus that this was the village's concern because the plague season was going on and there has been a family who had been travelling home, not because of Covid-19 illness. The team continued to ask residents who are registered as ODP or PDP to come out to the terrace of the house so that they can check their temperature and complaints and ensure that they are healthy and can carry out activities as well as monitoring health protocols (wearing masks, washing hands with soap and sunbathing at 08.00-09.00 a.m.).

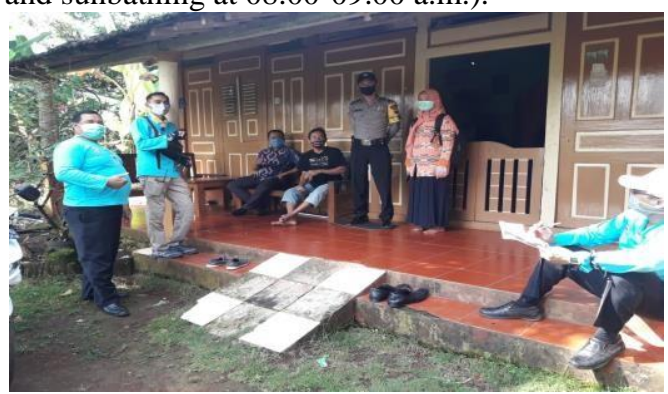

Figure 4.2.2 Home visit with Devices, Village Midwives, Babinkamtibmas and Donorojo URK Mobile Team.

This is in line with Stangl (2019) explaining that multi-component interventions can seek to support individual sufferers in overcoming the stigma they experience and internalized. In addition, it is necessary to reach the community members to change the harmful norms through community dialogue or engaging local leaders to share anti-stigma messages [10].

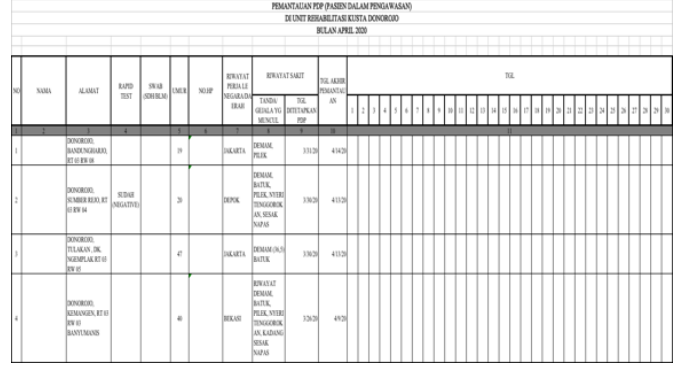

Figure 4.2.3 PDP Monitoring Checklist

Out of the 41 ODPs and 5 PDPs monitored through home visits with related stakeholders, none were found undergoing inpatient care at the hospital. Families and local residents treat the patients fairly according to health 
protocols. Thus patients were not stressed, their immunity increased and their families and local residents did not discriminate and stigmatize Covid-19 ODPs and PDPs.

This cross-cutting approach will support a more efficient and effective response to addressing significant sources of poor health outcomes globally. So, we need a framework for reducing health stigma and discrimination that provides innovative and alternative methods to conceptualize and respond to health-related stigma [10]. This makes it is easier to build better social resilience.

\subsection{CONCLUSSION}

To reduce the covid-19 stigma, it is necessary to make innovation related to the covid-19 service policies through advocacy and collaborative governance. Meanwhile, in the policy implementation stage to achieve social resilience, a home visit is necessary to provide a sense of calm for Covid-19 patients as well as to campaign for removing stigma and discrimination. Thus, we need a framework for eliminating stigma and health discrimination in policymakers and implementing policies.

\section{ACKNOWLEDGMENT}

This article is the concern of URK Donorojo RSUD Kelet in the attempt of eradicating the stigma of Covid-19 and funded by BLUD Kelet Hospital.

\section{REFERENCES}

[1] L.A. Abdillah, Stigma Terhadap Orang Positif COVID-19, http: eprints.binadarma.ac.id, 2020

[2] WHO (2020e) WHO Director-General's opening remarks at the media briefing on COVID-19 - 11 March 2020. Available at: https://www.who.int/dg/speeches/detail/who -directorgeneral-s-opening- remarks-at-the- mediabriefing-on-covid-19 11-march-2020

[3] Infeksi Emerging Kemkes RI (2020) COVID-19. https://covid19.kemkes.go.id/ (Accessed: 20 Mei 2020)

[4] Jateng Tanggap COVID-19.

http:corona.jatengprov.go.id (Accessed: 10 Mei 2020)

[5] WHO (2020d) Social Stigma associated with
COVID-19: A guide to preventing and addressing.Available https://www.who.int/docs/defaultsource/coronaviruse/covid19-stigma- guide.pdf.

[6] Zahrotunnimah, Langkah Taktis Pemerintah Daerah Dalam Pencegahan Penyebaran Virus Corona Covid-19 di Indonesia, Maret 2020. doi: 10.15408/sjsbs.v7i3.15103

[7] Ansell, Chris, and Alison Gash. Collaborative governance in theory and practice. Journal of Public Administration Research and Theory 18:543-71, 2008.

[8] Sururi, A. Inovasi Kebijakan Dalam Prespektif Administrasi Publik Menuju Terwujudnya Good Public Policy Governance. Journal Spirit Publik. 2017.

[9] WHO (2020c) Naming the coronavirus disease (COVID-19) and the virus that causes it. Available at: https://www.who.int/emergencies/diseases/novelcoronavir us-2019/technical-guidance/naming-thecoronavirusdisease-(covid-2019)-and-the-virusthatcauses-it (Accessed: 14 April 2020)

[10] Anne L. Stangl, et all. The Health Stigma and Discrimination Framework: a global, crosscutting framework to inform research, intervention development, and policy on health-related stigmas, BMC Medicine. 2019. 17:31 https://doi.org/10.1186/s12916- 019-1271-3

[11] Arboleda-Flórez, J. 'What causes stigma?', World Psychiatry, 1(1), 2002. pp. 25-26. Available at: https://www.ncbi.nlm.nih.gov/pmc/articles/P MC1489829/

[12] De-Graft Aikins, A. 'Reframing applied disease stigma research: A multilevel analysis of diabetes stigma in Ghana', Journal of Community and Applied Social Psychology, 16(6), 2006. pp. 426-441. doi: 10.1002/casp.892

[13] Kirk Emerson et all. An Integrative Framework for Collaborative Governance, JPART 22:1-29.2011. https: //doi:10.1093/jopart/mur011

[14] Sahya Anggara dkk. Inovasi Kebijakan Publik Tentang Pencegahan Dan Penanggulangan Corona Virus Disease 19 (Covid-19) Di Jawa Barat, Fakultas Ilmu Sosial Ilmu Politik Universitas Islam Negeri Bandung, 2020

[15] Mudjia Rahardjo, Studi Kasus Dalam Penelitian Kualitatif: Konsep Dan Prosedurnya, 2017. http://Repository.UinMalang.Ac.Id/1104/1/Studi-Kasus-Dalam- PenelitianKualitatif.Pdf 